Wydanie w otwartym dostępie na licencji CC BY-NC-ND

This is an open access article under the CC BY-NC-ND license

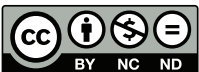

\author{
Anna Lusińska \\ orcid.org/0000-0001-9279-4992
}

Uniwersytet Gdański

anna.lusinska@ug.edu.pl

\title{
ZARZADZANIE MEDIAMI SPOŁECZNOŚCIOWYMI W KONTEKŚCIE REALIZACJI PROJEKTÓW SPOŁECZNYCH SKIEROWANYCH PRZECIW MOWIE NIENAWIŚCI NA PRZYKŁADZIE PROJEKTU GRAŻYNA ŻARKO. KATOLICKI GŁOS W INTERNECIE
}

\author{
Abstract \\ SOCIAL MEDIA MANAGEMENT IN THE CONTEXT OF SOCIAL PROJECTS \\ AGAINST HATE SPEECH ON THE EXAMPLE OF THE PROJECT GRAŻYNA \\ ŻARKO. CATHOLIC VOICE ON THE INTERNET
}

Argument/objective: In view of the growing negative phenomenon of hate speech in the social media, targeted informational and educational activities in the public sphere seem important and necessary, for the common good and in the common interest, as a reminder of respect for the other person and respect for his or her rights. The aim of the article is to identify and analyse the selected project in terms of the occurrence, spread and scale of the hate speech phenomenon in social media and to try to evaluate this type of communication. Research methods, research questions: The text uses methods such as case study, desk research and media content analysis. The following research questions were posed: how does the broadly understood civil society, and in principle its representatives, try to oppose hate speech? For what purpose are social projects against hate speech created and implemented? Do social projects against hate speech show the scale of this phenomenon, its horror and immorality? What image of Poles, including Polish Internet users (and in the case of a selected YouTube project) emerges from them? and how do they exchange views on the subject and what conclusions do they draw from this? Results and conclusions: Research has shown that when modern society, which is largely civic, starts to rebel against injustice, lack of respect for others, or socially unacceptable behaviour, including hate speech, it reaches for tools of opposition, among others. Projects such as these are born in this way: Incubator of Ideas, \#StopMowieNienawiści, or the title one, analysed: Grażyna Żarko. Catholic Voice on the Internet. This non-commercial, over two months long project, and at the same time a media, Internet provocation carried out in the form of 
a Polish vlog, showed not only the enormous scale of the problem of "verbal violence" of Polish Internet users on the example of YouTube, but also the lack of preventive actions and responsibility, or rather criminal consequences, for example, incurred for this type of conduct. Cognitive value: The article is part of the discussion on the way and quality of communication of Polish society, with particular emphasis on hate speech, through new media.

Keywords: civil society, hate speech, new media, social media, social projects

\section{Wstęp}

W wieku nowych technologii, których istnienie i rozprzestrzenianie się nie byłoby możliwe bez Internetu, także międzyludzka komunikacja zmienia swoje formy. Choć już dawno przestała być wyłącznie komunikacją bezpośrednią, dyskusją „twarzą w twarz", to dopiero od niedawna, właśnie za sprawą technologii, a ściślej odpowiednio wykorzystywanych, czy raczej zarządzanych nowych mediów, odbywa się ponad granicami, niezależnie od barier, w szeroko rozumianej przestrzeni. Otwartość, niezależność, szybkość przepływu informacji, często też anonimowość komunikacji mogą się wydawać pozytywne i w znacznej mierze tak jest. Jednak gdy do głosu dochodzą negatywne emocje, przekazywane w formie komunikatów wyrażających brak poszanowania drugiego człowieka, a nawet wrogość wobec innej osoby lub grupy (choć granica między wrogim aktem mowy a wypowiedzią swobodną z racji swojej nieostrości wydaje się trudna do ustalenia), ujawnia się jej negatywny aspekt. W Internecie, za pośrednictwem różnych narzędzi, w tym mediów społecznościowych (którymi zarządzanie m.in. pod kątem sprawowania nad nimi kontroli wydaje się niewykonalne), wolność słowa (do której prawo w państwie demokratycznym ma każda jednostka, każdy obywatel) - rozumiana niewłaściwie, anonimowa i niezmiennie bezkarna, przeobraża się w mowę nienawiści.

Kiedy więc społeczeństwo, określane współcześnie obywatelskim, wpisujące się w koncepcję dobra wspólnego i wolności jednostki, podejmujące się działań w sferze publicznej dla dobra wspólnego i we wspólnym interesie, zaczyna się buntować przeciw niesprawiedliwości, brakowi szacunku wobec drugiego człowieka czy zachowaniom społecznie nieakceptowalnym, w tym przeciw szeroko pojętej mowie nienawiści, sięga m.in. po narzędzia sprzeciwu (w tym prowokacje). Rodzą się $\mathrm{w}$ ten sposób projekty takie jak: Inkubator idei, \#StopMowieNienawiści czy tytułowy: Grażyna Żarko. Katolicki głos w Internecie.

Wobec szerzącego się negatywnego zjawiska mowy nienawiści w social mediach ważne i potrzebne wydają się zatem ukierunkowane działania społeczne, mające na celu ogólnospołeczną edukację pod kątem zmiany zachowań z nieaprobowanych na akceptowalne społecznie. Celem artykułu uczyniono identyfikację oraz analizę wybranego projektu pod kątem ukazania występowania, rozprzestrzeniania się i skali zjawiska mowy nienawiści w social mediach, a także próbę oceny tego typu komunikacji. Realizacja celu opracowania wymagała postawienia następujących 
pytań badawczych: w jaki sposób szeroko rozumiane społeczeństwo obywatelskie, a w zasadzie przede wszystkim jego przedstawiciele starają się przeciwstawiać mowie nienawiści? W jakim celu powstają i są realizowane projekty społeczne skierowane przeciw mowie nienawiści? Czy projekty społeczne przeciw mowie nienawiści pokazują skalę tego zjawiska, jego okropieństwo i niemoralność? Jaki obraz Polaków, w tym polskich użytkowników Internetu (a w przypadku wybranego projektu - serwisu YouTube), się z nich wyłania? W jaki sposób wymieniają oni poglądy na dany temat i jakie płyną $\mathrm{z}$ tego wnioski?

W części teoretycznej artykułu zdefiniowano pojęcia społeczeństwa obywatelskiego, wolności słowa, mowy nienawiści oraz odniesiono się do realizacji projektów społecznych, wykazując istniejący między nimi związek. W części empirycznej dokonano natomiast analizy wybranego projektu społecznego skierowanego przeciw mowie nienawiści, zatytułowanego: Grażyna Żarko. Katolicki głos w Internecie, realizowanego w social mediach. Metodami pozyskania danych, wykorzystywanymi w różnym stopniu, były: case study, desk research oraz analiza zawartości mediów (forów internetowych).

\section{Polskie społeczeństwo obywatelskie}

Termin „społeczeństwo obywatelskie” z racji swojej wieloznaczności nie jest łatwy do opisania. Historycznie nawiązuje do myśli greckiej, współcześnie natomiast odnosi się do społeczeństwa pluralistycznego, określanego liberalno-demokratycznym (Zieliński, 2006, s. 96). Definicje społeczeństwa obywatelskiego łączy jedna wspólna cecha - zachowuje ono autonomię wobec instytucji państwa (Gouldner, 1986, s. 356) i z tej perspektywy wydaje się jednym z najważniejszych osiągnięć współczesnej demokracji.

W ujęciu politologicznym (klasycznym) określa się je jako: „społeczeństwo, w którym zespół instytucji oraz różnego typu dobrowolnych, spontanicznych organizacji, związków i stowarzyszeń jest podstawą samodzielnego, wolnego od ingerencji państwa, rozwoju obywateli, a zarazem stanowi wyraz ich własnej aktywności, inicjatyw i potrzeb" (Antoszewski, Herbut, 2004, s. 414). Z jednej strony jest więc zespołem idei, $z$ drugiej - zbiorem pewnych form samoorganizacji społecznej w celu realizacji tych idei (Szacki, 1997, s. 5-6).

Idea społeczeństwa obywatelskiego zawiera w sobie nie tylko koncepcję dobra wspólnego, ale i koncepcję wolności jednostki. Współczesne społeczeństwo obywatelskie stało się swego rodzaju przestrzenią zakreśloną między państwem a jednostką, obszarem niezależności i wolności (głównie ekonomicznej). Obszary jego funkcjonowania wyznaczane są przez indywidualizm, prywatność, pluralizm, możliwość zrzeszeń, prowadzenie dyskusji i komunikację (Pietrzak, 2016, s. 12-13). W społeczeństwie obywatelskim ważne są wzajemne relacje między obywatelami, 
ich aktywność wykraczająca poza prywatne interesy jednostek. Podejmują się oni działań w sferze publicznej dla dobra wspólnego i we wspólnym interesie.

Kształtowanie się polskiego społeczeństwa obywatelskiego rozpoczęło się wraz z wychodzeniem Polski spod reżimu sowieckiej zależności, w obliczu zachłyśnięcia się niezależnym Zachodem i jego kulturowością. Z początku dość mozolnie rozwijająca się polska obywatelskość na dorobku, biegnąca za bogatymi krajami Europy i uwielbionymi Stanami Zjednoczonymi Ameryki, stanęła u progu procesu społecznego przeobrażania się. Polacy z obywateli biorących, czy raczej przyjmujących pomoc i czekających na to, co się wydarzy, zaczęli zmieniać się w dzielących się sobą i tym, co udało im się zgromadzić, w dążących do szeroko pojętych zmian, aktywnych w sferze publicznej dla dobra wspólnego i we wspólnym interesie. Polskie społeczeństwo obywatelskie stało się: „areną życia społecznego i politycznego, przestrzenią zaangażowania i uczestnictwa, w której wolność stowarzyszeń jest zasadą życia obywatelskiego, a społeczeństwo funkcjonuje dobrze, gdy istnieją: prawodawstwo, wolne instytucje i silna władza centralna, tak by między obywatelami i władzą panowała równowaga” (Pietrzak, 2016, s. 14).

Społeczeństwo obywatelskie stanowi platformę komunikacyjną, a może raczej przestrzeń dla dialogu rozumianego jako wymiana myśli, poglądów, idei (Załęski, 2012, s. 122-141). Powszechne i aktualne są w nim postulaty poszerzania tej dialogowej przestrzeni, zwiększania obecności dialogu czy jego pogłębiania. Dialog w polskim społeczeństwie obywatelskim jest więc wartością. Wartości, stworzone $\mathrm{w}$ bezosobowym i niepewnym świecie-To i wykorzystywane przez osobisty i pewny świat-Ty (Stewart, 2012, s. 39-41), istnieją bez względu na to, czy je wybieramy, czy nie, i jaką przywiązujemy do nich wagę. Wartości są jak drogowskazy, znaki indeksowe wyznaczające kierunki działań jednostek i społeczeństw. Definiują nie tylko charakter ludzkich dążeń, ale i cele grupowe oraz społeczne, a nawet zmiany społeczno-cywilizacyjne. Szukający własnej wartości człowiek dąży do realizacji różnych wartości pośrednich (Zawadzka, 2012, s. 41). Co więcej, dla każdego wartość może stanowić coś zupełnie innego. Dla jednych sposobem pozyskania własnej wartości bywa posiadanie władzy, dla drugich służenie innym i postępowanie według zasad moralnych. Jednak, co ciekawe, Michał Bachtin - człowiek, od którego we współczesnej myśli humanistycznej zaczęła się moda na szeroko pojmowany dialog, nie traktował go w sposób normatywny jako wartość. Podkreślił natomiast, że każde, nawet najmniejsze współdziałanie językowe może być elementem określonego, choć nie zawsze i nie dla wszystkich oczywistego, dialogu. Na takiej perspektywie opiera się wywodzone z myśli Bachtina tak zwane „podejście dialogiczne", zakładające, że pozornie monologiczne wypowiedzi mogą być elementami szerszej interakcji, wymiany poglądów i zdań (Zarycki, 2010, s. 5).

W polskim społeczeństwie obywatelskim wszyscy aktorzy znajdujący się $\mathrm{w}$ polu komunikacji jako strony uczestniczące $\mathrm{w}$ debatach posiadają podobne formalne prawa: do zabierania głosu, przedstawienia swoich problemów, żądań, aspiracji, bycia wysłuchanym, szanowanym, polemiki oraz uzyskania odpowiedzi na 
pytania od kompetentnych czynników. Jednak, jeśli dyskusja toczy się na nieco grząskim, można by rzec, badanym, ale niedającym się zbadać dokładnie i w związku z tym niezbadanym gruncie - w Internecie, okazuje się, że aktorom wydaje się, iż w zakresie komunikacji mogą znacznie więcej. Przypuszczalnie przyczynia się do tego ich świadomość, w znacznej mierze, anonimowości, a co za tym idzie - braku konsekwencji, czyli nieponoszenia odpowiedzialności za słowa i czyny. Co jednak znaczy więcej? Obejmuje wszystko (akty agresji w mowie werbalnej i niewerbalnej oraz uznawane za niedopuszczalne i nieakceptowalne społecznie czyny), co nazwać można potocznie „mową nienawiści” w polskim społeczeństwie (Bulandra, Kościółek, 2016, s. 13).

\section{Mowa nienawiści w polskim społeczeństwie}

Wolność słowa uznaje się za najważniejszą z wolności, swobód obywatelskich. Stanowi ona fundament państwa demokratycznego. Pomaga zatem państwu, chociażby w procesie sprawowania władzy, a społeczeństwu i poszczególnym jednostkom np. w samorealizacji. Niestety nie wszystkie państwa na świecie przestrzegają tej zasady.

Wolność słowa zapewnia więc swoim obywatelom każde demokratyczne państwo. W Polsce wolność słowa - potwierdzona po raz pierwszy w Statucie wiślickim (Uruszczak, 1999), czyli zbiorze praw wydanym przez Kazimierza III Wielkiego w 1347 roku - stanowi konstytucyjne, czyli zagwarantowane przez Konstytucję Rzeczypospolitej Polskiej artykułami 14, 25, 49, 53 i 54 (Konstytucja, 1997), prawo do publicznego wyrażania własnego zdania, opinii i poglądów (za pośrednictwem wszelkich dostępnych środków ich uzewnętrzniania), a także ich poszanowania przez innych. Oznacza też prawo dostępu do krajowych i zagranicznych istniejących źródeł informacji, do pozyskiwania i rozpowszechniania uzyskanych informacji, zakaz cenzury środków społecznego przekazu oraz koncesjonowanie prasy.

Wolność słowa znajduje również regulacje w wielu innych, nie tylko państwowych (Kodeks cywilny, Kodeks karny, Ustawa o ochronie tajemnicy państwowej, Prawo autorskie czy Prawo prasowe), ale i międzynarodowych aktach prawnych, takich jak: Międzynarodowy pakt praw obywatelskich i politycznych czy Europejska konwencja o ochronie praw człowieka i podstawowych wolności. Ta konstytucyjna wolność ma, jak widać, dość szerokie znaczenie.

Nie istnieje wolność słowa niczym nieograniczona, co potwierdzają wyżej wymienione akty prawne. Niemniej jednak brak ostrości granic dopuszczalnego oddziaływania słowami, prowadzącego do aktywizacji i wzmacniania postaw nieakceptowalnych społecznie w społeczeństwach demokratycznie stabilnych i ponoszenia odpowiedzialności za dalece niestosowne wypowiedzi, doprowadził do szerzenia się negatywnego zjawiska, jakim jest mowa nienawiści. Ten specyficzny rodzaj przemocy zagraża równowadze społecznej, bezpieczeństwu - jednemu 
z dziesięciu uniwersalnych typów wartości wyodrębnionych na podstawie analizy wartości ludzi w różnych kulturach, krajach oraz wyznających różne religie ${ }^{1}$. Poza tym debata nad mową nienawiści wiąże się z kwestią istnienia konfliktu między dwiema wartościami: wolnością słowa oraz dobrami osobistymi danej jednostki. Zwolennicy poglądu uznającego, że wolność słowa jest wartością najwyższą, krytykują samo pojęcie „mowa nienawiści”. Twierdzą, że może być ono interpretowane jako zamaskowana chęć usunięcia opinii propagujących nienawiść poza nawias debaty publicznej. Ich zdaniem wolność słowa nie powinna gwarantować możliwości swobodnego wypowiadania opinii, zwłaszcza jeśli opinie te odczuwane są przez inne osoby lub grupy jako obraźliwe, szydzące czy krzywdzące.

Mową nienawiści (odpowiednik angielskiego terminu hate speech) określane są negatywne emocjonalnie ustne oraz pisemne wypowiedzi, wymierzone przeciwko grupom lub jednostkom ze względu na reprezentowanie określonych poglądów, opinii, idei czy domniemaną lub faktyczną przynależność do danej grupy, tworzone na podstawie antyspołecznych uprzedzeń i stereotypów (Humanity in Action). Do wyznaczników mowy nienawiści można zaliczyć m.in. nadmierne uogólnianie negatywnej cechy (np. negatywne stereotypy grup obcych), przypisywanie szczególnie negatywnych cech lub uczynków osobom lub grupom, uwłaczającą leksykę, dehumanizację przez stosowane analogie lub metafory, lekceważenie czy podważanie rytuałów poważania (np. protekcjonalne traktowanie), okazywanie wyższości bądź niedopuszczanie do głosu, a także stosowanie katalogowania i zestawień (Nijakowski, 2018, s. 115). Wyznacznikiem jest również przedmiot nienawiści, krytyki, np. zbiorowość, do której przynależący ma charakter przypisany, np. ze względu na płeć, kolor skóry, orientację seksualną, narodowość, etniczność, niepełnosprawność oraz język ojczysty (Nijakowski, 2018, s. 115). Narzędzie to służy rozpowszechnianiu szeroko pojętej dyskryminacji (Hasło: mowa nienawiści).

Termin ten znalazł także ujęcie definicyjne w dorobku legislacyjnym Rady Europy w 1997 roku w Rekomendacji R (97) 20 (Recommendation No. R (97) 20, 1997), choć już w 1992 roku Rada zwracała uwagę na rasistowskie i ksenofobiczne treści w grach komputerowych (Recommendation No. R (92) 19, 1992). Mową nienawiści określono w nim: „każdą formę wypowiedzi, która rozpowszechnia, podżega, propaguje lub usprawiedliwia nienawiść rasową, ksenofobię, antysemityzm lub inne formy nienawiści oparte na nietolerancji, włączając w to nietolerancję wyrażaną w formie agresywnego nacjonalizmu lub etnocentryzmu, dyskryminacji lub wrogości wobec mniejszości, migrantów lub osób wywodzących się ze społeczności imigrantów"2. Do tej definicji także dzisiaj najczęściej odnoszą się w swych dokumentach europejskie instytucje, chociażby takie jak Europejski Trybunał Praw Człowieka, organizacje pozarządowe, eksperci oraz obrońcy praw człowieka.

1 Do uniwersalnych typów wartości należą: osiągnięcia, samokierowanie, życzliwość, uniwersalizm, tradycja, konformizm, stymulacja, hedonizm, władza, bezpieczeństwo. Zob. Schwartz, 1996.

2 Załącznik do Rekomendacji Komitetu Ministrów Rady Europy nr R (97) 20, przyjętej 30 października 1997 roku. Zob. Recommendation No. R (97) 20, 1997. 
Kongres Prawników Polskich w jednej z uchwał stwierdził, że mowa nienawiści jest: „jednym z najpoważniejszych zagrożeń dla zarówno trwałości społeczeństwa obywatelskiego, jak i demokracji. Jest ona bowiem żywym narzędziem wykorzystywanym nie tylko przez zwykłych obywateli, ale nade wszystko stanowi oręż w rękach polityków czy osób chcących wpływać na społeczne nastroje. Sprzyja temu rozpowszechnione poczucie bezkarności wśród hejterów” (Sobański, 2019).

Badania socjologiczne, prowadzone przez znane ośrodki badania opinii publicznej (takie jak np. CBOS), wskazują, że w Polsce to negatywne zjawisko rozpowszechniło się w ostatnich latach. Mowy nienawiści doświadcza niemal codziennie znaczna część obywateli, co prowadzi do groźnych konsekwencji, zwłaszcza dla młodzieży, szczególnie podatnej na agresywne i sugestywne oddziaływania. To niepokojące zjawisko powinno być stanowczo zwalczane zgodnie z prawem i przy współudziale wszystkich instytucji.

Ponieważ u źródeł każdego społeczeństwa obywatelskiego leży pragnienie, by żyć we wspólnocie wolnych oraz równych obywateli, to także obywatele polskiego społeczeństwa łączą się w celu realizacji określonych wartości. Podejmują różne działania nie dla realizacji celów politycznych czy zysku, ale z motywacji płynącej z wyznawanych wartości (np. szacunku do innych), dla dobra wspólnego. Tworzą i realizują różne projekty społeczne (także ogólnospołeczne kampanie informacyjne), wśród których mieszczą się chociażby takie, które stanowczo sprzeciwiają się szeroko pojętej mowie nienawiści: Inkubator idei: transformacja, demokracja i prawa człowieka (projekt innowacyjnie dotykający problematyki mowy nienawiści w przestrzeni wirtualnej wobec różnych grup mniejszościowych [Kampania Inkubator idei: transformacja, demokracja i prawa człowieka]), \#StopMowieNienawiści (projekt zwracający uwagę opinii publicznej na problem mowy nienawiści w stosunku do mniejszości etnicznych, seksualnych i wyznaniowych, skierowany do młodzieży szkolnej w wieku 15-18 lat, ponieważ nie tylko styka się ona, dużo częściej niż dorośli, z mową nienawiści, ale też jest bardziej narażona na szkodliwy wpływ mowy nienawiści, wykazując jednocześnie większe przyzwolenie na używanie takich wypowiedzi (Kampania \#StopMowieNienawiści]), a także tytułowy projekt Grażyna Żarko. Katolicki głos w Internecie.

\section{Mowa nienawiści polskiego społeczeństwa w nowych mediach - kazus projektu Grażyna Żarko. Katolicki głos w Internecie}

Niekomercyjny, ponaddwumiesięczny projekt Grażyna Żarko. Katolicki głos w Internecie (Projekt „Grażyna Żarko”, 2012), a zarazem medialna, internetowa prowokacja (odwołująca się do funkcjonujących w polskim społeczeństwie stereotypów i podsycająca istniejące dyskryminacje), realizowana w formie polskiego vloga, rozpoczął się w maju 2012 roku i trwał do 21 lipca. Przedstawiał on fikcyjną postać 
- Grażynę Żarko (w której rolę wcieliła się aktorka, zatrudniona na potrzeby projektu emerytowana nauczycielka Anna Lisak), około 50-letnią nauczycielkę o konserwatywnych poglądach, można by nawet rzec - religijną fanatyczkę, która za pomocą wideobloga w serwisie YouTube ${ }^{3}$ w krytyczny sposób wyrażała swoje radykalne poglądy i dawała rady nie tylko na temat zachowywania się i wychowywania polskiej młodzieży, ale i zachowań polskiego społeczeństwa oraz jego stosunku do religii. Bohaterka zyskała skrajnie negatywną opinię wśród internautów.

Autorzy, wrocławscy dziennikarze, producent telewizyjny Grzegorz Cholewa oraz scenarzysta i reżyser Bartłomiej Szkop, znani odbiorcom z wcześniejszego, również rozpoznawalnego wideobloga, zatytułowanego Baśka Blog, celem projektu uczynili podjęcie problemu „przemocy słownej” w Internecie (Gr@żyna). Starając się zmierzyć ze źle pojmowaną wolnością słowa oraz agresją, które są m.in. youtube’ową codziennością, wydali dwanaście odcinków bloga (Kruczek, 2012). Te trwające nieco powyżej minuty filmiki, rozpoczynające się melodią rozbrzmiewającą z kościelnych organów, zostały wyświetlone ponad dwa miliony razy. Uruchamiające lawinę komentarzy i wiele innych internetowych aktywności projektowe realizacje, mające na celu sprowokowanie polskiej społeczności internetowej do dyskusji na poruszane $\mathrm{w}$ filmikach tematy i tym samym ujawnienie prawdziwego oblicza kultury słowa w mediach społecznościowych, wymknęły się spod kontroli. Reakcje, jakie wywołał eksperyment, przeraziły nie tylko autorów, ale także aktorkę i obserwatorów. Nikt z nich nie spodziewał się aż takiej fali hejtu. W związku z licznymi obelgami i groźbami śmierci skierowanymi w stronę Grażyny Żarko (która, przez większość internautów, była uważana za postać prawdziwą) postanowiono zakończyć projekt, udostępniając na kanale ujawniający prawdę osiemnastominutowy film zatytułowany Grażyna.

Na potrzeby przybliżenia projektu oraz jego analizy wybrane zostały trzy najpopularniejsze, ale uznane jednocześnie za najbardziej kontrowersyjne, odcinki. W filmie zatytułowanym Dzisiaj o piosence Kokoko Euro Spoko z 14 czerwca 2012 roku, trwającym 1 minutę i 19 sekund, mającym 930771 wyświetleń, Grażyna Żarko wypowiedziała się na temat przeboju ludowego zespołu Jarzębina pt. Kokokoko Euro spoko. Piosenkę określiła utworem satanistycznym, a wykonujące ją kobiety - sektą wprowadzonych do show-biznesu podstarzałych, naćpanych emerytek po LSD lub amfetaminie. Nie omieszkała, niejako przy okazji, obrazić też polskiego społeczeństwa, twierdząc, że: „Polaczki-prostaczki będą mieli co śpiewać do kiełbasy czy piwka", by na koniec ogłosić, aby użytkownicy darowali sobie wulgarne komentarze pod jej filmami, ponieważ: „Pan Bóg i tak Wam wybaczy” (Dzisiaj o piosence Kokoko Euro Spoko, 2012).

W trwającym 1 minutę i 15 sekund odcinku pt. Dzisiaj o maltretowaniu zwierząt z 25 czerwca 2012 roku, obejrzanym 1174593 razy, podjęła temat znęcania

3 Serwis internetowy założony w lutym 2005 roku. Umożliwia on bezpłatne umieszczanie, a także odtwarzanie strumieniowe, ocenianie i komentowanie filmów. 
się nad zwierzętami w kontekście (lubianej swego czasu nie tylko przez młodszych użytkowników) gry Angry Birds. Bohaterka obowiązujące w grze zasady katapultowania ptaka, w celu zniszczenia nim twierdzy świń i zdobycia punktów, przełożyła na rzeczywistość. Podkreśliła, że takie zachowanie odbija się na umysłach polskich dzieci (uczą się one w ten sposób zabijania zwierząt), a wszystko to, zdaniem Żarko, dzieje się: „za masońskie pieniądze z Ameryki” (Dzisiaj o maltretowaniu zwierząt, 2012).

W kolejnym filmiku, który odtworzono 740785 razy, zatytułowanym Dzisiaj kilka rad dla nauczycieli, wyemitowanym 30 czerwca 2012 roku, Grażyna Żarko zaprezentowała metody i techniki skutecznego wychowywania. Radząc nauczycielom, jak okiełznać niesfornych uczniów, sugerowała stosowanie bezpośrednich metod, do których zaliczyła chociażby klęczenie z doniczką, bicie linijką „po łapach”, targanie za uszy, pisanie sto razy słów „będę grzeczny”, prace społeczne, konfiskatę komórek, a także kary finansowe. Do metod psychologicznych natomiast - oślą ławkę, ośmieszanie przed klasą, odmawianie różańca, poniżanie, a nawet usuwanie ze znajomych na Facebooku. Swoje, trwające 1 minutę i 23 sekundy, porady zakończyła zdaniem: „Drodzy nauczyciele, bierzcie i korzystajcie z tego wszyscy. Szczęść Boże" (Dzisiaj kilka rad dla nauczycieli, 2012).

Bohaterka projektu od początku wiedziała, że musi się przygotować na konfrontację z nieprzyjemnymi komentarzami. Jednak ani ona, ani autorzy nie spodziewali się aż tak agresywnych reakcji. Projekt, wobec ogromnej fali internetowej nienawiści, która doprowadziła do jego zakończenia, skłonił z czasem użytkowników sieci do dyskusji. Wielu internautów, gdy mistyfikacja wyszła na jaw i okazała się prowokacją, skasowało swoje negatywne komentarze. Po przeszło siedmiu latach udało się jednak dotrzeć do ich pozostałości i przeanalizować niemal $500 \mathrm{z}$ nich. W przypadku 373 wpisów odnotowano duży stopień agresywności. W 412 przypadkach wystąpiły wulgaryzmy odnoszone do poglądów bohaterki, skierowane bezpośrednio do jej postaci lub współdyskutantów, a nawet samego projektu. W 431 komentarzach wulgaryzmy pełniły też funkcję wyrażania emocji. I choć znaczna liczba wpisów na temat projektu, jego bohaterki oraz wolności słowa i mowy nienawiści nie nadaje się do cytowania, warto przytoczyć kilka $\mathrm{z}$ nich ${ }^{4}$.

W zamieszczonych poniżej przykładach takich komentarzy zachowano pisownię oryginalną. Podano też internetowe nicki autorów komentarzy oraz czas wskazujący, kiedy wpisy zostały umieszczone na forum. Dodatnie bądź ujemne oznaczenia liczbowe określają liczbę podkomentarzy, pozytywnych bądź negatywnych, w odniesieniu do danej wypowiedzi. Celem zamieszczenia w artykule wybranych opinii uczyniono wyłącznie przybliżenie fragmentu kontrowersyjnej dyskusji, która (nie biorąc pod uwagę wulgaryzmów) nie odbiega znacząco od całości opinii na powyższy temat, nie zaś ocenę wypowiedzi konkretnych użytkowników.

4 Wszystkie przywołane komentarze pochodzą ze strony www.wykop.pl (Wykop.pl, 2017). 
zwora 2 lata 6 mies. temu via Android +317

co tu gadać. jedna z najlepszych prowokacji artystycznych tego wieku. nie trzeba udawać seksu z papieżem by opowiedzieć o dzisiejszych dziwacznych czasach.

SzewskaPasja 2 lata 6 mies. temu +34

@krowi_placek: Z jednej strony wszystko ok. Z drugiej jednak „źle pojmowana wolność słowa”. Niech rzuci kamieniem ten kto po usłyszeniu, że owa postać jest pedagogiem i głosi w miejscu pracy swoje „tezy”, nie łapał automatycznie wk\$?\#a. Czym innym jest zachowywanie się jak nosacz z dostępem do internetu a czym innym odniesienie się do faktycznego materiału, w który niestety coraz częściej bezkrytycznie wierzymy.

bartek422 2 lata 6 mies. temu +23

@krowi_placek: dobitny przykład na inteligencję tych wszystkich kretynów z psychiatryka zwanego potocznie youtube ... pięknie ukazali nowoczesną gimbazę, która składa się przeważnie z gównozjadów, którzy do niczego nie doszli poza nauczeniem się obsługiwania kamerki na komputerze tatusia, bądź mamusi, zwanych potocznie starymi... żal.

jeloo 2 lata 6 mies. temu via Android +12

@SzewskaPasja Wolność słowa wcale nie oznacza, że można wszystko. Należy zawsze pamiętać, że nasza wolność kończy się tam, gdzie zaczyna się wolność innej osoby. Dotyczy to również wolności słowa. Owszem, można się odnieść do jakiejś kwestii. Ale to co się działo w tym przypadku nie miało nic wspólnego z jakimś „odniesieniem” się, bo o wolności słowa nie wspomnę.

SzewskaPasja 2 lata 6 mies. temu +117

@jeloo: Racja. Czasem jednak treści w tym projekcie mówiły o naruszaniu wolności innych osób, nie tylko słowa. Dla mnie to bardzo podobne zjawisko jakby ktoś zrobił projekt gdzie ktoś głosi skrajne tezy a potem się dziwi, że ludzie go chcą udupić. Publikowanie tak kontrowersyjnych treści zawsze powinno być napiętnowane. Oczywiście do pewnego stopnia.

jeloo 2 lata 6 mies. temu via Android +9

@SzewskaPasja Oczywiście zgadzam się z Tobą. Problem w tym, że obnaża to agresję ludzi. Niektórzy nie potrafią utrzymać nerwów na wodzy. Niektórzy nie potrafią pozbyć się swojej frustracji. Szef opieprza bo dedlajny, matka opieprza bo jedynki, żona opieprza bo brak pracy itd. Trafiają do sieci i znajdują obiekt na którym można się wyżyć. Normalny człowiek się wk?\#\%i, ale punkt po punkcie wyjaśni gdzie dana osoba się myli i dlaczego taka jest reakcja. Normalna osoba wyjaśni, że nie chodzi o poglądy jako takie, tylko o sposób ich realizacji. Często też zwyczajnie to oleje, bo nie uderza to w nią w żaden sposób. Ot kolejny oszołom. Projekt pokazał, jak łatwo jest przekroczyć granicę tej wolności. Działania innych osób nigdy nie powinny prowadzić do przekroczenia wolności z Naszej strony. 
Stajemy się bowiem tacy sami, albo nawet gorsi od tych, których staramy się potępić. Ja sam się wk?\#\%iałem jak słuchałem jej farmazonów. Ale w życiu by mi nie przyszło do głowy, żeby pisać tak okropne rzeczy czy życzyć lub grozić jej śmiercią.

Anaris 2 lata 6 mies. temu -9

@jeloo: Masz racje, wolność słowa oznacza że można wszystko powiedzieć. Szok że istnieją ameby twojego pokroju nie rozumiejący tak prostego konceptu. Nie możesz przy pomocy słowa ograniczyć czyjejś wolności. Czy ja naprawdę muszę to tłumaczyć? Twoje p@!@@?enie nie odnosi się do wolności słowa tylko jakiegoś, istniejącego tylko w twojej głowie zbioru antylogicznych zasad moralnych. Trolle w internecie powyzywają i odejdą, ale takie trutnie jak ty to prawdziwy rak.

zaltar 2 lata 6 mies. temu 0

@Anaris: To, że mówisz co chcesz zawsze ma swoje konsekwencje społeczne. W normalnym nieautorytarnym kraju jak gadasz głupoty ktoś może przestać chcieć się z tobą kontaktować. Jak kłamiesz ktoś może wytoczyć ci proces. Jak rozpowszechniasz groźby czy siejesz nienawiść z nawoływaniem do morderstw możesz iść do więzienia. Tak to się już kręci, wypowiedziane słowa mogą mieć oczywiście swoje pozytywne konsekwencje. Czy są to więc formy ograniczające wolność jako taką - na upartego tak, ale wynikające z tego, że jesteśmy ludźmi i żyjemy w społeczeństwach ${ }^{5}$.

Poza wulgarnymi komentarzami obrażającymi bohaterkę, zamieszczanymi pod filmikami oraz na forach, bardziej i mniej znani vlogerzy nagrywali polemiki z jej opiniami. Niektórzy odbiorcy posunęli się nawet do zachowań ordynarnych, nieprzyzwoitych, nieakceptowalnych społecznie, chociażby takich jak oddawanie moczu na jej podobiznę czy grożenie śmiercią. Inni unicestwiali ją w grze komputerowej (np. Perypetie Roja z „Grażyna Żarko”, 2013). W 2016 roku opinie Grażyny Żarko pojawiły się nawet na polskich tubach remixerskich. Przebojami wśród internautów okazały się przeróbki znanych hitów, chociażby takich jak Thank You Very Much Margaret (Grażyna Żarko ft. Margaret, 2016), More Than You Know Axwell \& Ingrosso (Grażyna Żarko - Ciagnij ptaka, 2018) czy słynny Alfabet $z$ Grażyną Żarko (2019).

\section{Podsumowanie}

Projekty takie jak Grażyna Żarko. Katolicki głos w Internecie można uznać za przykład zaplanowanego, edukacyjnego działania społecznego, które poprzez ukazanie brutalnej prawdy o jakości komunikowania się (można by zaryzykować stwierdzenie, że większości) polskiego społeczeństwa w sieci (co potwierdzają zamieszczone

5 Wszystkie komentarze pochodzą ze strony wykop.pl i odnoszą się do filmowego podsumowania zakończonego projektu Grażyna Żarko. Katolicki głos w Internecie (Wykop.pl, 2017). 
w tekście przykładowe komentarze), a także zawstydzenie użytkowników (komentarze po zakończeniu emisji vloga), miało w konsekwencji, wobec ogólnopolskiej dyskusji społecznej, jaka wywiązała się w mediach, wytłumaczyć niewłaściwość i nieakceptowalność stosowanego w mowie hejtu, zwracając uwagę tak na kulturę języka, jak i tę osobistą.

Ten nietypowy, wręcz przewrotny projekt, zaplanowany w swojej formule jako generator złych emocji, wytwarzający napięcie społeczne i prowokujący ożywioną dyskusję Polaków na zadany temat, powstał w celu nie tylko zmierzenia się z problemem mowy nienawiści w Internecie, wynikającym ze źle pojmowanej wolności słowa oraz agresji, które są youtubeową codziennością, ale i wskazania użytkownikom języka polskiego potocznego właściwych zachowań komunikacyjnych.

Projekty takie jak ten przytoczony w tekście pokazują skalę zjawiska mowy nienawiści, jego okropieństwo i niemoralność. Sprowokowana wypowiedziami Grażyny Żarko społeczność użytkowników Internetu, zwłaszcza serwisu YouTube, odpowiedziała wyłącznie negatywnymi, w znacznej mierze wulgarnymi, wpisami, groźbami, a nawet trudnymi do opisania (w znaczeniu moralnym) czynami pod adresem bohaterki projektu. Niektórzy, w celu podkreślenia, wzmocnienia przekazywanych emocji w komunikacji internetowej albo po to, by ich komentarze nie zostały usunięte lub ukryte przez moderatora za nieprzestrzeganie ustalonych na forum zasad, posiłkowali się emotikonami. Obraźliwe i pełne nienawiści komentarze umieszczano pod każdym z dwunastu odcinków vloga oraz na poświęconych projektowi forach.

Po ujawnieniu prowokacji i przymusowym zakończeniu projektu wywiązała się ogólnopolska dyskusja społeczna, pokazująca nie tylko medialną moc kształtowania warunków życia społecznego, ale także brak tolerancji i dwa oblicza polskich internautów. Wielu skasowało swoje negatywne komentarze. Od części z nich do autorów projektu dotarły tysiące wiadomości z wyrazami skruchy i przeprosinami dla Anny Lisak (tytułowej Grażyny Żarko). Vlogerzy publikowali oficjalne przeprosiny w serwisie YouTube. Chcąc się zrehabilitować i pokazać dobrą stronę polskiej sieci, internauci na portalu Indiegogo.com zainicjowali zbiórkę na wczasy dla bohaterki projektu. Byli też tacy, którzy pozostali niewzruszeni w swoich poglądach oraz postawach wobec projektu i jego bohaterki. Nawet w odniesieniu do podejmowanych pozytywnych zachowań i inicjatyw nie obyło się bez kąśliwych komentarzy: „Teraz nagle wszyscy skruszeli i zmądrzeli, bo dowiedzieli się, że to wszystko było ustawiane, żal mi was” (Projekt „Grażyna Żarko”, 2012).

Bartłomiej Szkop i Grzegorz Cholewa w jednym z poprojektowych wywiadów zwrócili, przy okazji tematu, uwagę na panujące $w$ mediach oraz Internecie różne standardy ponoszenia odpowiedzialności za słowa. Przywołali oni przykład potwierdzający taki stan rzeczy: „W trakcie tego projektu rozgrywał się w Polsce ogólnonarodowy lincz na dwóch znanych dziennikarzach, którzy na falach radiowych niesmacznie zażartowali na temat pracujących w Polsce kobiet 
pochodzenia ukraińskiego. Dziennikarze z radia ponieśli konsekwencje, natomiast komentatorzy z sieci zawsze są bezkarni” (Kruczek, 2012).

Celem niniejszego artykułu było przeanalizowanie i zobrazowanie wybranego projektu społecznego o charakterze edukacyjnym pod kątem występowania, rozprzestrzeniania się i skali zjawiska mowy nienawiści w social mediach. Przywołany $\mathrm{w}$ tekście socjologiczny projekt, zrealizowany siedem lat temu w mediach społecznościowych, oraz przykłady zamieszczanych pod nim "nienawistnych” komentarzy jego odbiorców - polskich użytkowników Internetu, a dokładnie serwisu YouTube - obnażyły skalę polskiego chamstwa i agresji w sieci. Stanowią one też klasyczny przykład tego, że pogarda, wrogość i nienawiść rodzą chęć odwetu w tej samej lub gorszej postaci. Brak bezpośredniego kontaktu sprawia, że komunikujący się stają się bardziej dosadni, nie przebierając w słowach. Projekt pokazał nie tylko, że wolność słowa nie oznacza, iż można wszystko powiedzieć, bo to, co i jak się mówi, może mieć nieprzewidziane konsekwencje społeczne, ale też, jak łatwo i szybko negatywne emocje nakręcają spiralę konfliktu, prowadząc do samounicestwienia zaangażowanych w nią stron.

\section{Bibliografia}

Antoszewski A., Herbut R. (2004). Leksykon politologii wraz z Aneksem o: reformie samorzadowej, wyborach do sejmu, prezydenckich oraz gabinetach rządowych. Wrocław: Wydawnictwo Alta2.

Bulandra A., Kościółek J. (2016). Przeciwdziałanie mowie nienawiści. Podręcznik dla środowiska politycznego. Kraków: Stowarzyszenie Interkulturalni PL.

Gouldner A.W. (1986). The Two Marxismus. Contradictions and Anomalies in the Development of Theory. New York: Palgrave.

Nijakowski L.M. (2018). Mowa nienawiści w świetle teorii dyskursu [w:] A. Horolets (red.), Analiza dyskursu w socjologii i dla socjologii. Toruń: Wydawnictwo Adam Marszałek.

Pietrzak E. (2016). Społeczeństwo obywatelskie globalne czy transnarodowe? [w:] A. Wojtaszak, A. Krawcewicz (red.), Wspótczesny wymiar społeczeństwa obywatelskiego, t. 1. Szczecin: Wydawnictwo Minerwa.

Schwartz S. (1996). Value Priorities and Behavior: Applying a Theory of Integrated Value System [w:] C. Seligman, J.M. Olson, M. Zann (eds.), The Psychology of Values: The Ontario Symposium, vol. 8. Mahwah, NJ: Lawrence Erlbaum Associates Publishers.

Stewart J. (2012). Komunikacja interpersonalna: kontakt między osobami [w:] J. Stewart (red.), Mosty zamiast murów. Podręcznik komunikacji interpersonalnej. Warszawa: Wydawnictwo Naukowe PWN.

Szacki J. (1997). Powrót idei społeczeństwa obywatelskiego [w:] J. Szacki (red.), Ani książe, ani kupiec: obywatel. Kraków: Wydawnictwo Znak.

Załęski P.S. (2012). Neoliberalizm i społeczeństwo obywatelskie. Toruń: Wydawnictwo Uniwersytetu Mikołaja Kopernika.

Zarycki T. (2010). Dylematy budowy przestrzeni komunikacji i dialogu Polaków [w:] J. Szomburg (red.), Jak poprawić komunikację i dialog Polaków? V Kongres obywatelski. Gdańsk: Wydawnictwo Instytutu Badań nad Gospodarką Rynkową. „Wolność i Solidarność, 30. 
Zawadzka A.M. (2012). Czy wartości majq znaczenie? O widocznych i niewidocznych konsekwencjach preferencji pewnych wartości nad innymi [w:] J. Szomburg (red.), Pomorze - jakie wartości, jaki rozwój? Gdańsk: Wydawnictwo Instytutu Badań nad Gospodarką Rynkową, „Wolność i Solidarność”, 43.

Zieliński E. (2006). Nauka o państwie i polityce. Warszawa: Wydawnictwo Elipsa.

\section{Źródła internetowe}

Alfabet z Grażyną Żarko (2019), https://www.youtube.com/watch?v=Rh7k4fyxNNw (dostęp: 29.10.2019).

Dzisiaj kilka rad dla nauczycieli (2012), https://www.youtube.com/watch?v=my6fpBp5crU (dostęp: 29.10.2019).

Dzisiaj o maltretowaniu zwierząt (2012), https://www.youtube.com/watch?v=8fn1LWHztxg (dostęp: 29.10.2019).

Dzisiaj o piosence Kokoko Euro Spoko (2012), https://www.youtube.com/watch?v=x_dYoV8IDQ8 (dostęp: 29.10.2019).

Gr@żyna, https://www.youtube.com/watch?v=xLIqyVsUnuk\&feature=plcp (dostęp: 29.10. 2019).

Grażyna Żarko - Ciagnij ptaka (Axwell ^ Ingrosso - More Than You Know/Parodia) (2018), https://www.youtube.com/watch?v=LVml4GYpLks (dostęp: 29.10.2019).

Grażyna Żarko ft. Margaret - Thank You Very Much (2016), https:/www.youtube.com/ watch?v=EFsqHO5wiRQ (dostęp: 29.10.2019).

Hasło: mowa nienawiści/język nienawiści, https://rownosc.info/dictionary/mowa-nienawisci-jezyk-nienawisci/ (dostęp: 26.10.2019).

Humanity in Action Polska, Czym jest mowa nienawiści?, https://uprzedzuprzedzenia.org/ czym-mowa-nienawisci/ (dostęp: 3.11.2020).

Kampania Inkubator idei: transformacja, demokracja i prawa człowieka, https://kampaniespoleczne.pl/internetowe-kampanie-przeciwko-hejtowaniu/ (dostęp: 29.10.2019).

Kampania \#StopMowieNienawiści, http://stopmowienienawisci.pl/ (dostęp: 29.10.2019).

Konstytucja Rzeczypospolitej Polskiej z dnia 2 kwietnia 1997 r. (1997), Dz.U. 1997 Nr 78 poz. 483, http://prawo.sejm.gov.pl/isap.nsf/download.xsp/WDU19970780483/U/D19970 483Lj.pdf (dostęp: 25.10.2019).

Kruczek M. (2012). Eksperyment Grażyna Żarko ujawnił dwa oblicza polskiego internetu [wideo], https://wroclaw.naszemiasto.pl/eksperyment-grazyna-zarko-ujawnil-dwa-oblicza-polskiego/ar/c2-2800654 (dostęp: 29.10.2019).

Perypetie Roja $z$ „Grażyna Żarko” (2013), https://www.youtube.com/watch?v=VSilGrQN59k (dostęp: 29.10.2019).

Projekt „Grażyna Żarko”, czyli jak wygląda chamstwo w sieci (2012), https://www.tvn24.pl/wiadomosci-z-kraju,3/projekt-grazyna-zarko-czyli-jak-wyglada-chamstwo-w-sieci,266320. html (dostęp: 29.10.2019).

Recommendation No. R (92) 19 of the Committee of Ministers to member states on video games with a racist content adopted on 19 October 1992 (1992), https://rm.coe.int/CoERMPublicCommonSearchServices/DisplayDCTMContent?documentId=09000016804d74f7 (dostęp: 29.10.2019).

Recommendation No. R (97) 20 of the Committee of Ministers to member states on "hate speech" adopted on 30 October 1997 (1997), https://rm.coe.int/CoERMPublicCommonSearchServices/DisplayDCTMContent?documentId=0900001680505d5b （dostęp: 29.10.2019). 
Sobański P. (2019). Zagadnienie możliwości i celowości zdefiniowania tzw. mowy nienawiści w prawie polskim, https://www.academia.edu/40140501/Adwokat_Piotr_Sobański_-_ Zagadnienie_możliwości_i_celowości_zdefiniowania_tzw._mowy_nienawiści (dostęp: 29.10.2019).

Uruszczak W. (1999). Statuty Kazimierza Wielkiego jako źródło Prawa Polskiego [w:] Studia z Dziejów Państwa i Prawa Polskiego 3, Studia_z_Dziejow_Panstwa_i_Prawa_Polskiego-r1999-t3-s97-115.pdf (muzhp.pl) (dostęp: 21.01.2021).

Wykop.pl (2017), https://www.wykop.pl/link/3703601/comment/44749727/\#comment-44749 727 (dostęp: 30.10.2019). 
